\section{A Pilgrim's Quest for the Divine}

By Lord Conway of Allington. Pp. 255. (London : Frederick Muller, Ltd., 1936.) 10s. 6d. net.

LORD CONWAY's book reminds one of a philosophical romance such as "Rasselas", or even "John Inglesant". Much of it is in dialogue, and the scene passes from place to place-Switzerland, Italy, the Andes, Spitsbergen. The writer has been a pilgrim in the physical as well as in the spiritual sense. This is not a systematic treatise; but readers can go on with interest, and take the ideas as they come-they are always suggestive and often ingenious. Not that it is a casual book, for it has been rewritten four times, the author tells us, and he is working out his point of view all the while.

The problem with which the book is largely concerned is that of time and its relation to eternity, especially in the light of the theory that time is a fourth dimension of space. Lord Conway asks whether this conception may not "involve an entire revolution in our ideas about both the present and a possible so-called future life". His theory is that we are living and active in a three-dimensional state which exists within a four-dimensional universe. As we pass through the latter (as a two-dimensional inhabitant of Flat-land might pass through our three-dimensional world), "we leave behind us in what we regard as the passage of time the result of our actions built into the structure of our lives". This enables Lord Conway to envisage something in the nature of the Pauline conception of a "spiritual body", built up by a life's activities much in the way that a crystal is built up.

The last pages of the book consist of extracts from a diary kept by the author while staying with a small Franciscan community on an island near Venice. These are of particular interest, and the author seems to plead for something in the nature of a modern Third Order of St. Francis.

"After all, St. Francis was not a mere visionary but a practical reformer. Why should not practical men of our day take up his work in a new form suit. able for our present needs? Has not the passion for worm-eaten speculation yet made victims enough ?"

The reader must come to this somewhat unconventional book with a sympathetic mind; but if he does so, he will find it very fruitful, even fascinating. J. C. H.

\section{Bibliographia Coleopterologica}

Pp. xv + 149-323. (Den Haag: W. Junk, 1935.) 10s.

THIs publication is a special cloth-bound catalogue issued by the well-known entomological publisher, Herr W. Junk, now of The Hague. While, in principle, it is a priced list of books, reprints and journals, bearing, in the main, upon insects of the order Coleoptera, in reality it serves a much wider purpose. It is, in fact, a partial bibliography of the order, which is accompanied by a most useful index, so arranged with cross-references that publications on practically every aspect of the order can be readily found. It is intended also to serve the purpose of marking the jubilee of Herr Junk's most famous publication, the "Coleopterorum Catalogus", which was begun in the year 1910 .

An interesting preface by S. Schenkling discusses the origin, history and purpose of this great work. The "Catalogus", which is now nearing completion, is the largest single work ever published dealing with the literature of any section of biology. It lists all the described species of beetles of the world, and the 141 parts (in twenty-one volumes), published to date, comprise 21,000 pages, containing the names, synonymy, distribution and taxonomic and biological literature of some $\mathbf{1 7 5 , 6 6 6}$ species. When completed, it will be comprised in thirty volumes, listing about 240,000 species in 134 families. The necessity for a reference work of this kind is borne out by the fact that its precursor - the Catalogue of Gimminger and Harold (1868-1876)-listed only 77,000 species.

\section{A Comprehensive Treatise on Inorganic and Theo-} retical Chemistry

By Dr. J. W. Mellor. Vol. 15 : Ni, Ru, Rh, Pd, Os, Ir. Pp. viii +816 . (London, New York and Toronto: Longmans, Green and Co., Ltd., 1936.) 63s. net.

VOL: 15 of "Mellor" includes nickel and five out of six elements of the platinum group. Only platinum itself remains, with a general index, to complete the final volume, which is described as "in the press". As the author's huge task approaches completion, the admiration called forth by its monumental character increases to a climax. For example, the reviewer was surprised to find his own name cited under nickel as joint author of a paper in which he himself had forgotten that this element was investigated. Such a thorough scouring of the literature can leave very few gaps to be filled up, and provides a wonderful guide to all the work done up to the date of compilation of the volume in question.

As in previous volumes, the dictionary aspect is relieved by occasional discussions, for example, on the atomic weight and valency of osmium, with special reference to the formulation of the tetroxide.

At this stage, no further commendation is needed, since in a short time the present notice will give place to congratulations when the final volume appears.

\section{Einführung in die angewandte Akustik :}

insbesondere in die neueren Probleme der Schallmes. sung, Schallübertragung und Schallaufzeichnung. Von Dr. H. J. von Braunmühl und Walter Weber. Pp. v+216. (Leipzig: S. Hirzel, 1936.) 9.20 gold marks.

From the physies point of view, this text is admirable. It covers most of the important applications of acoustics in the field of electrical communication, amongst which may be mentioned the measurement of performance of loudspeakers and microphones, the recording and reproduction of sound in its varied forms, acoustic perspective and the technical acoustics of enclosures. The last chapter appropriately deals with the measurement of fidelity of speech in com. munication systems, but the more difficult problem of measuring the fidelity in musical reproduction is not discussed.
L. E. C. H. 